\title{
IMPLEMENTASI MODEL KOMUNIKASI KESEHATAN MELALUI PENYEBARAN INFORMASI JAMINAN KESEHATAN MASYARAKAT JAWA BARAT
}

\author{
Agus Rahmat \\ Program Studi Hubungan Masyarakat, Fakultas Ilmu Komunikasi Universitas Padjadjaran, Jln. Raya Jatinangor \\ Km.21. HP 08122198354.E-mail: agusrahmat.fikom@gmail.com.

\section{Susi Perbawasari} \\ Program Studi Hubungan Masyarakat, Fakultas Ilmu Komunikasi Universitas Padjadjaran, Jln. Raya jatinangor \\ Km.21. Hp.0811214790.E-mail: susieperbawasari@yahoo.com.
}

\section{Feliza Zubair}

Program Studi Hubungan Masyarakat, Fakultas Ilmu Komunikasi Universitas padjadjaran, Jln. Raya jatinangor, Km.21.Hp.085722557144.E-mail : felizaherison@yahoo.com.

\section{Aang Koswara}

Program Studi Hubungan Masyarakat, Fakultas Ilmu Komunikasi Universitas Padjadjaran, Jln. Raya jatinangor Km.21. Hp 081312390399.E-mail: aangkoswara@unpad.ac.id

Naskah diterima tanggal 15 Januari 2014, direvisi tanggal 28 Mei 2014, disetujui tanggal 3 Juni 2014

\section{HEALTH COMMUNICATION MODEL IMPLEMENTATION THROUGH INFORMATION DISSEMINATION OF WEST JAVA'S PUBLIC HEALTH INSURANCE}

\begin{abstract}
Every behavior is based on knowledge, therefore the success of public health insurance (Jamkesmas) program conduct by the government for poor community require communication and socialization of the program, through various existing channels. How health communication model implemented by the government in order to disseminate Jamkesmas information particularly in West Java region? The purpose of this research is to discover the direction of information stream in socialization of Jamkesmas program, through quantitative approach. In addition, sampling use multistage cluster sampling with 180 respondents. The result of the research shows that interpersonal communication with formal opinion leaders act as the main channel for poor community to obtain information. It means that the public target for strengthening or success of Jamkesmas socialization is opinion leaders such as head of the neighborhood or local community and cadres.
\end{abstract}

Keywords: communication, opinion leaders, public target.

\begin{abstract}
Abstrak
Setiap perilaku berlandas pada pengetahuan, oleh karena itu untuk keberhasilan program Jaminan Kesehatan Masyarakat yang dilakukan pemerintah untuk masyarakat kurang mampu mempersyaratkan dilakukannya komunikasi atau sosialisasi atas program tersebut, melalui berbagai saluran yang ada. Bagaimana model komunikasi kesehatan yang diimplementasikan
\end{abstract}


pemerintah dalam menyebarkan informasi Jamkesmas khususnya di wilayah Jawa Barat ? Tujuan penelitian ini adalah mengetahui arah aliran informasi yang terjadi dalam sosialisasi program Jaminan Kesehatan Masyarakat, dengan menggunakan pendekatan kuantitatif. Pengambilan sampel menggunakan multistage cluster sampling, jumlah responden 180 orang. Hasil penelitian menunjukkan komunikasi yan bersifat antarpribadi dengan para opinion leaders formal sebagai saluran utama masyarakat kurang mampu dalam memeroleh informasi. Ini berarti bahwa publik target untuk penguatan atau keberhasilan sosialisasi Jaminan Kesehatan Masyarakat adalah opinion leaders seperti ketua Rukun Warga ataupun Rukun Tetangga serta kader.

Kata kunci: komunikasi, opinion leaders, publik target.

\section{PENDAHULUAN}

Asuransi Kesehatan Masyarakat Miskin merupakan metode penyelenggaraan pemeliharaan kesehatan dengan mutu yang terjamin serta pembiayaan yang dibiayai oleh pemerintah. Sesuai dengan namanya, sasaran dari program ini adalah masyarakat miskin dan masyarakat tidak mampu yang membutuhkan pelayanan kesehatan di Pusat Kesehatan Masyarakat (Puskesmas) dan jaringannya, sepert Pos Pelayanan Terpadu (Posyandu) serta layanan rujukan medis lanjutan di Rumah Sakit baik pemerintah maupun swasta yang di tunjuk, Balai Kesehatan Mata Masyarakat (PP4) atau Balai Kesehatan Indera Mata (BKIM), kecuali masyarakat yang memiliki jaminan pemeliharaan/asuransi kesehatan lainnya.

Meskipun program ini sudah lama dilaksanakan, namun sering ditemui fenomena yang menunjukkan kekurang pahaman masyarakat terhadap program. Mulai dari isu ketidaktepatan kepemilikan kartu Jaminan Kesehatan Masyarakat miskin sampai pada konflik sebagai bentuk kekecewaan masyarakat miskin yang butuh layanan kesehatan dengan pelayan kesehatan (healt provider).

Banyak aspek yang menyebabkan munculnya fenomena kekurangtepatan persepsi masyarakat atas niat baik yang diaplikasikan melalui program pemerintah di bidang layanan kesehatan. Namun dari sekian banyak hal, aspek yang penting untuk diamati terkait dengan ditemukannya persepsi yang kurang tepat dari masyarakat mengenai jaminan kesehatan masyarakat miskin oleh pemerintah adalah aspek aktivitas komunikasi dalam menyosialisasikan niat baik pemerintah ini.

Ada beberapa alasan mengapa komunikasi menjadi penting dan menjadi sorotan terkait dengan kekurangtepatan persepsi mayarakat dalam program Jamkeskin (Embong, 2003). Pertama, terkait dengan pemikiran salah seorang ilmuwan komunikasi seperti Megee. Secara tegas Megee mangatakan bahwa komunikasi merupakan pra kondisi untuk sebuah perubahan yang direncanakan. Terkait dengan penelitian ini, yang dimaksud dengan perubahan yang direncanakan terebut adalah layanan kesehatan yang diberikan pemerintah bagi masyarakat miskin. Kedua, pemikiran dari Rosario Breid. Bagi Breid komunikasi merupakan katalisator, fasilitator, penghubung, antara rakyat dengan para penentu kebijakan (pemerintah). Konsekunsi pemikiran Breid adalah bila komunikasi dilakukan secara benar, hal yang akan muncul adalah persepsi yang muncul di masyarakat akan memiliki kesejalanan dengan apa yang dipikirkan oleh pemerintah sebagai penentu atau pembuat kebijakan mengenai Jamkeskin yang pada awal tahun 2013 kemudian namanya diubah menjadi Jamkesmas (Gorman dan David McLean, 2003).

Berdasar atas fakta yang ada atau muncul mengenai persepsi masyarakat atas jaminan kesehatan masyarakat, dan pemikiran kedua ahli komunikasi sebagaimana dideskripsikan, maka masalah yang muncul adalah bagaimana model komunikasi kesehatan yang diimplementasikan pemerintah dalam menyebarkan informasi Jamkesmas khususnya di wilayah Jawa Barat? 
Merujuk masalah sebagaimana dirumuskan, maka penelitian ini bertujuan untuk mengetahui karakteristik penerima kartu Jaminan Kesehatan Masyarakat, mengetahui kepemilikan kartu Jaminan Kesehatan Masyarakat, serta mengetahui arah aliran informasi yang terjadi dalam sosialisasi program Jaminan Kesehatan Masyarakat.

Penelitian ini memiliki nilai strategis untuk dilakukan terutama dikaitkan dengan manfaat praktis, yaitu sebagai informasi ilmiah yang bisa dijadikan sebagai salah satu pertimbangan dalam memperbaiki program Jamkesmas di masa depan. Hal seperti ini juga menjadi substansi dari penelitian tindak (actions research) yang dipakai dalam penelitian ini.

\section{LANDASAN KONSEP}

Orang memberi sebutan zaman sekarang dengan berbagai istilah yang dikaitkan dengan komunikasi, seperti: zaman baru komunikasi, abad komunikasi elektronik, era informasi, dan lain sebagainya, walaupun bagi Schramm (1988) dikutip Nasution (1989) "Sebutan tidaklah menjadi soal", yang paling penting dan utama, bahwa setiap perkembangannya komunikasi membawa manusia pada keadaan yang lebih baik.

Menurut Pramonosidi, et.all, manusia hanya akan melakukan perubahan sehingga terjadi perubahan, kalau memiliki persepsi, motivasi dan kemauan, serta semangat untuk melakukan pembaharuan. Sementara itu persepsi, motivasi, pemikiran berpangkal pada informasi. Pramonosidi, et.all berpendapat bahwa "Informasi yang disampaikan oleh media massa, baik media cetak, radio, televisi, dan lain-lain secara jelas akan mengubah persepsi, pemikiran, cara hidup dan memotivasi para penerima informasi (Sapuan, 1994).

Persoalannya adalah apa dan bagaimana komunikasi dilakukan agar komunikasi yang dilakukan mencapai apa yang diinginkan? Turner dan Van Den Ban serta Hawkins menginformasikan jawaban atas pertanyaan ini.

Salah satu hal menarik dari apa yang dikemukakan Turner dan Van Den Ban serta Hawkins adalah pada persoalan keharusannya mengaitkan aktivitas komunikasi dengan pengetahuan, bahasa, dan sikap, serta keinginan khalayak sasaran informasi. Kondisi ini bisa diartikan bahwa, untuk keberhasilan kegiatan komunikasi dipersyaratkan pemahaman karakteristik khalayak sasaran (selanjutnya disebut dengan publik) oleh komunikator (Van den Ban dan Hawkins, 1999).

Dalam kaitan atau kontek penelitian ini maka bisa disimpulkan menurut pendapat ketiga para ahli sebagaimana yang dirujuk ini adalah, "untuk keberhasilan kegiatan sosialisasi atas Program Jaminan Kesehatan Masyarakat maka pihak yang melakukan sosialisasi harus memahami karakteristik masyarakat yang menjadi khalayak sasarannya (masyarakat)".

Pemikir lain yang memiliki relevansi tinggi dengan pemikir sebelumnya serta dinilai berguna dalam memahami penelitian ini adalah pemikiran Stiglitz dalam Rogers dan Kincaid (2002) melalui nilai informasinya. Menurutnya sedikit saja ketidaksempurnaan informasi dapat berdampak besar terhadap keberhasilam atau kegagalan ekonomi. Pemikir lain adalah Markus melalui ragam teori Resistensi, pada intinya teori ini menghimpun berbagai pemikiran tentang penolakan atau resistensi terhadap sistem informasi (Pendit, 2007).

Ahli lain yang pemikirannya demikian dinilai relevan untuk menjadi rujukan dalam melakukan analisis atas penelitian ini adalah pemikiran Ira Kaufman, dkk. dalam Zaltman (1972). Pemikirannya berisi mengenai upaya mengubah sikap dan perilaku individu atau kelompok sasaran oleh agen perubahan yang berusaha memperkenalkan gagasan atau inovasi ke dalam satu sistem sosial. Inti pemikirannya kemudian dituangkan dalam sebuah bagan manajemen perubahan seperti ditunjukan melalui bagan berikut : 


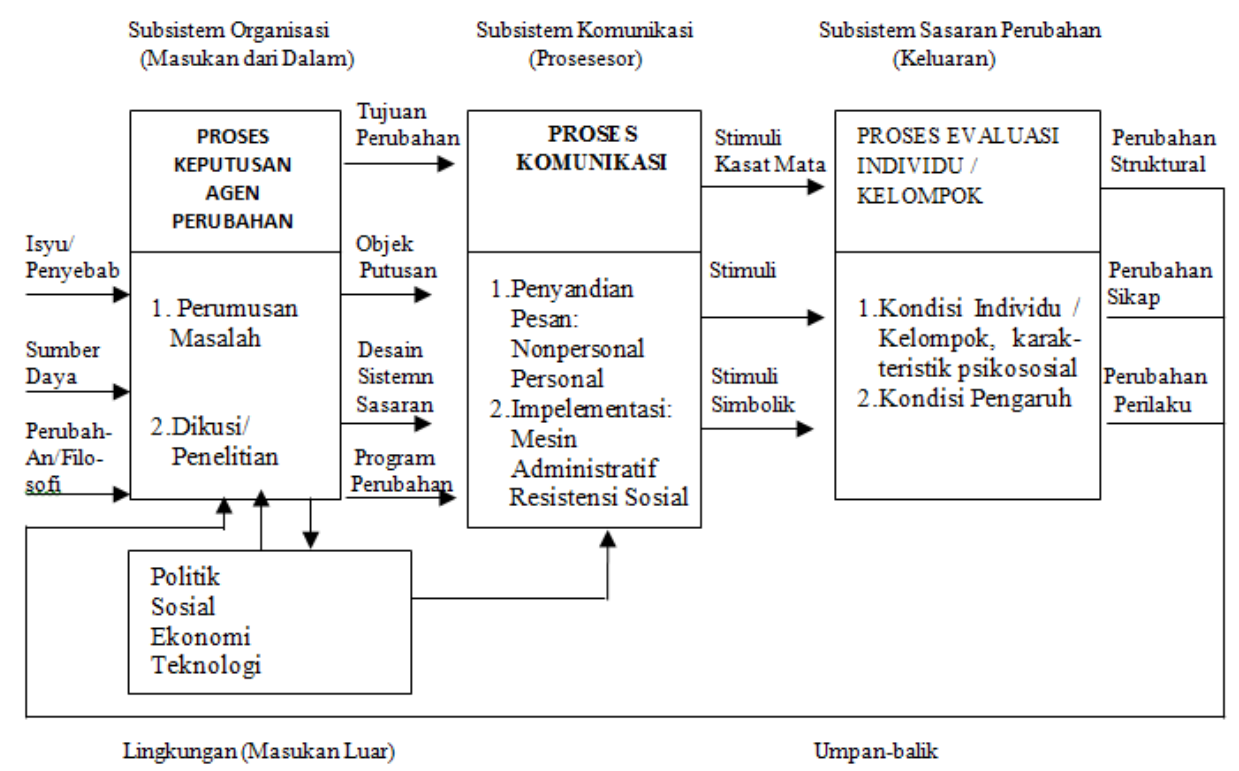

Sumber: Zaltman,1972.

\section{Gambar 1 \\ Sistem manajemen Perubahan}

Selain pemikiran ahli dari luar, beberapa pemikir ahli dari indonesia juga memiliki pemikiran yang sama, salah satunya adalah pemikiran Gumilar Rusliwa Somantri. Menurut Gumilar, teori dan pengalaman yang sukses itu ada dalam konteks masyarakat tertentu (Pikiran Rakyat, 2007). Ini berarti bahwa ketepatan sebuah teori, konsep bahkan sebuah panduan hanya akan terjadi jika memiliki kesejalanan dengan suasana yang melingkupinya.

Dalam kaitan dengan persoalan penelitian ini, maka bisa diartikan bahwa nilai guna dan pengaruh dari sebuah komunikasi baik bermedia maupun langsung akan lebih bergantung pada relevansinya bagi khalayak sasaran ketimbang kualitas formalnya" (McBride, 1983).

\section{METODE PENELITIAN}

Penelitian ini menggunakan Metode Survei Penjelasan (Explanatory Survey Method) yaitu suatu penelitian penjelasan terhadap peristiwa atau keadaan (explanation). Penjelasan ini erat kaitannya dengan pertanyaan apa penyebab atau apa yang memengaruhi terjadinya suatu peristiwa atau keadaan dan akibat yang ditimbulkannya (Kriyantono, 2006). Dalam hal ini kuesioner digunakan sebagai instrumen utama pengumpul data penelitian (Singarimbun, 1998).

Berdasar atas konteks dan masalah penelitian, tampak bahwa unit analisis dalam penelitian ini adalah individu yang menjadi pemegang kartu Jaminan Kesehatan Masyarakat yang dulu disebut Askeskin, ini berarti populasi dalam penelitian ini adalah masyarakat penerima Jamkesmas (Askeskin) dan pernah mendapatkan pelayanan kesehatan. Sebagai konsekuensinya, maka populasi penelitian yang dilakukan tampak demikian banyak, oleh karena itu dilakukan pengambilan sampel dengan menggunakan multistage cluster sampling.

Berdasar data di tahun 2009, di Jawa Barat terdapat 1.030 puskesmas yang tersebar di 17 kabupaten dan 9 kota. Berdasarkan atas jumlah kabupaten dan kota maka wilayah penelitian selanjutnya mengambil tiga (3) yang terdiri dari dua (2) kabupaten yaitu Indramayu dan Garut, serta satu (1) kota yaitu Bandung.

Pemilihan Kabupaten Indramayu dan Garut dikaitkan dengan konteks penelitian, di mana persoalan kemiskinan yang sering kali 
identik dengan masyarakat yang berprofesi petani dan nelayan, sementara Kota Bandung terkait dengan kemiskinan di wilayah urban.

Dari masing-masing kabupaten dan kota ditentukan 90 responden sehingga total responden mencapai 180. Dari jumlah responden ini selanjutnya peneliti membagi dalam karakteristik kerja Puskesmas meliputi Puskesmas penyelenggara rawat jalan saja dan puskesmas yang menyelenggarakan rawat jalan dan rawat inap. Data mengenai Puskesmas di Jawa Barat ditunjukkan melalui tabel 1 berikut :

Tabel 1

Puskesmas di Jawa Barat

\begin{tabular}{|c|c|c|c|c|c|c|c|}
\hline No & Kabupaten & $\begin{array}{c}\text { Jum } \\
\text { Kecamatan }\end{array}$ & $\begin{array}{c}\text { Jum } \\
\text { Puskesmas }\end{array}$ & No & Kota & $\begin{array}{c}\text { Jum } \\
\text { Kecamatan }\end{array}$ & $\begin{array}{c}\text { Jum } \\
\text { Puskesmas }\end{array}$ \\
\hline 1 & Bogor & & 101 & 1 & Bogor & & 24 \\
\hline 2 & Sukabumi & & 58 & 2 & Sukabumi & & 15 \\
\hline 3 & Cianjur & & 45 & 3 & Bandung & 29 & 71 \\
\hline 4 & Bandung & & 61 & 4 & Cirebon & & 21 \\
\hline 5 & Garut & 42 & 64 & 5 & Bekasi & & 31 \\
\hline 6 & Tasikmalaya & & 40 & 6 & Depok & & 61 \\
\hline 7 & Ciamis & & 51 & 7 & Cimahi & & 11 \\
\hline 8 & Kuningan & & 37 & 8 & Tasikmalaya & & 20 \\
\hline 9 & Cirebon & & 53 & 9 & Banjar & & 9 \\
\hline 10 & Majalengka & & 30 & & & & \\
\hline 11 & Sumedang & & 32 & & & & \\
\hline 12 & Indramayu & 31 & 50 & & & & \\
\hline 13 & Subang & & 40 & & & & \\
\hline 14 & Purwakarta & & 20 & & & & \\
\hline 15 & Karawang & & 40 & & & & \\
\hline 16 & Bekasi & & 39 & & & & \\
\hline \multirow[t]{3}{*}{17} & Bandung Barat & & 31 & & & & \\
\hline & Jumlah & & 767 & & Jumlah & & 263 \\
\hline & Total & & & & & & 1030 \\
\hline
\end{tabular}

Sumber: Data Puskesmas Di Jawa Barat tahun 2009.

\section{HASIL PENELITIAN DAN PEMBAHASAN}

Berdasarkan hasil penelitian melalui wawancara dan angket yang disebar, hasilnya menunjukkan bahwa dilihat dari karakteristik ekonomi, masyarakat pemegang kartu Jamkesmas dicirikan dengan tingkat ekonomi yang rendah, seperti ditunjukkan melalui gambar pendapatan berikut:

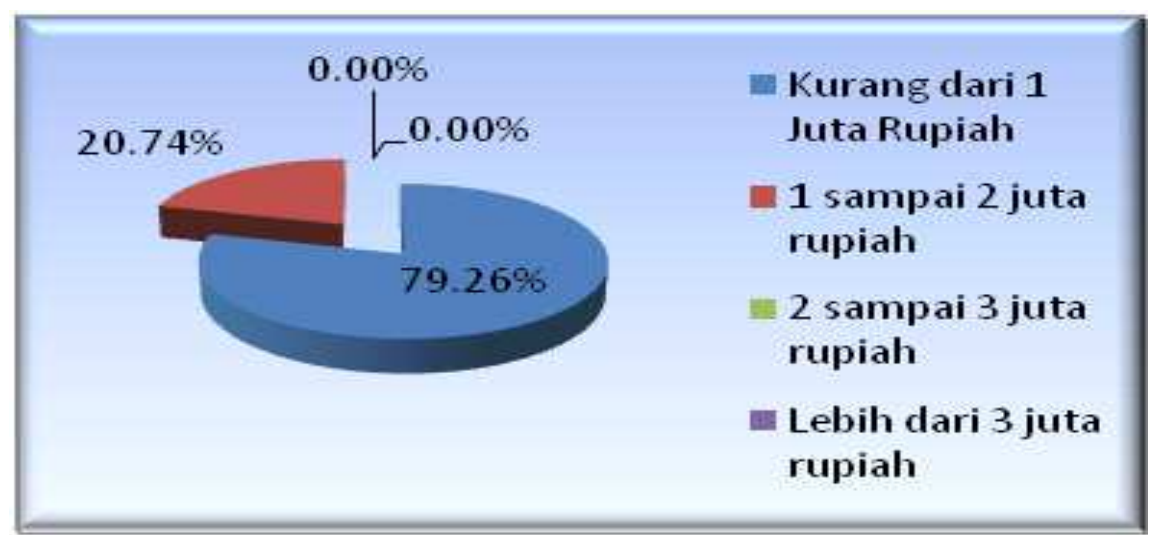

Gambar 1

Tingkat Pendapatan Responden 


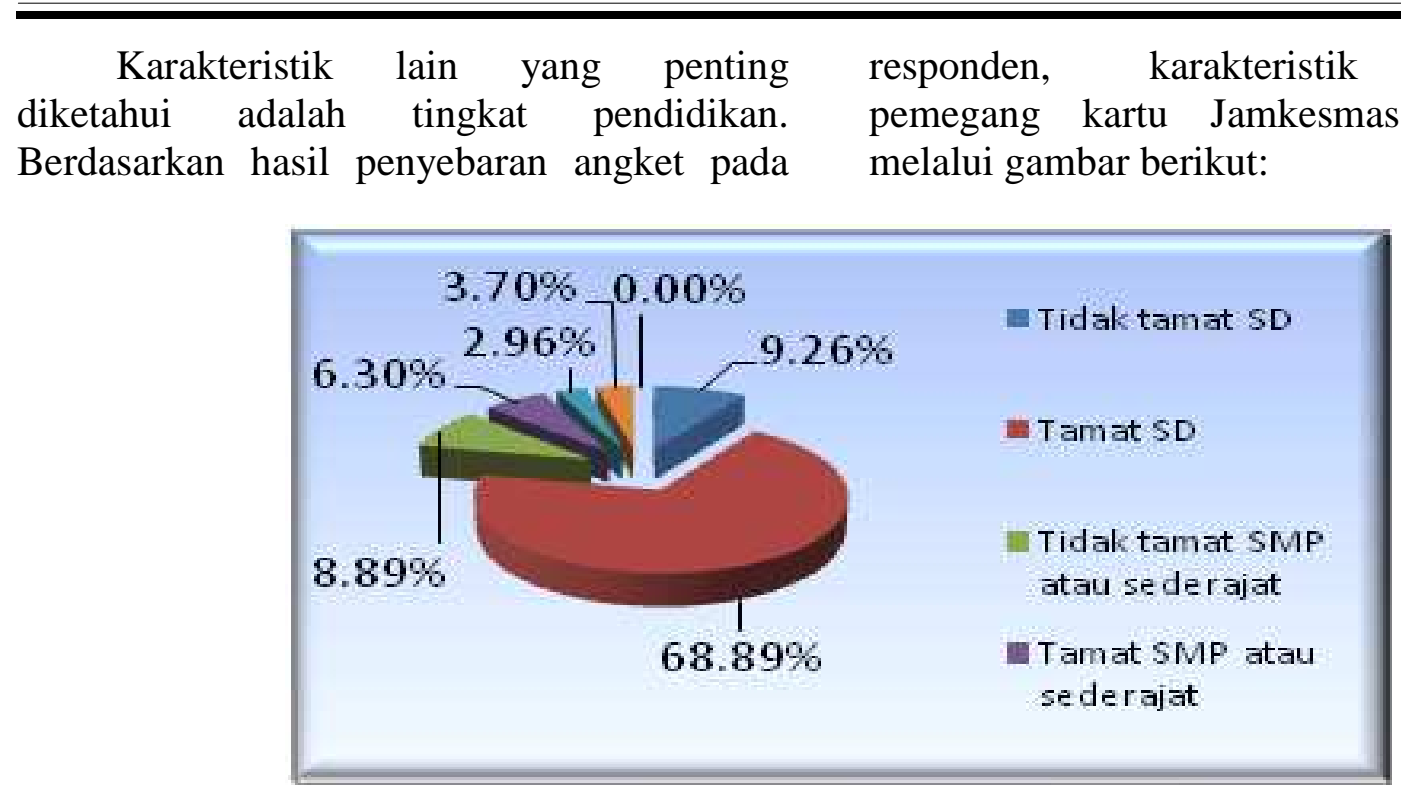

Gambar 2

Tingkat Pendapatan Responden

Hal menarik yang bisa diungkap dari gambar pendapatan dan pendidikan dalam penelitian ini adalah pertama mengenai kepemilikan kartu Jamkesmas yaitu, mayoritas pemegang kartu Jamkesmas adalah masyarakat yang berpendapatan rendah dan tingkat pendidikan yang kurang. Hal menarik lainnya dari penelitian ini adalah bahwa mayoritas responden adalah mereka yang berpendapatan rendah yang sekaligus juga berpendidikan rendah, ini bisa diartikan bahwa temuan dari penelitian ini memperkuat temuan atau konsep yang sudah ada selama ini antara lain hasil kajian Bank Dunia tahun
1980 tentang kemiskinan dan pembangunan, yang hasilnya dan sekaligus rekomendasinya adalah "untuk mengatasi kesenjangan sosial ekonomi masyarakat miskin sehubungan dengan pembangunan manusia tidak lain adalah kesempatan pemenuhan gizi, pelayanan kesehatan, cukup penghasilan, kesempatan memperoleh pendidikan, ..." (Supriatna, 1997).

Selanjutnya rekomendasi atas kajian dituangkan dalam bentuk model kebijakan pembangunan kemiskinan (Policy Against Poverty) yang ditunjukan melalui gambar 1 berikut:

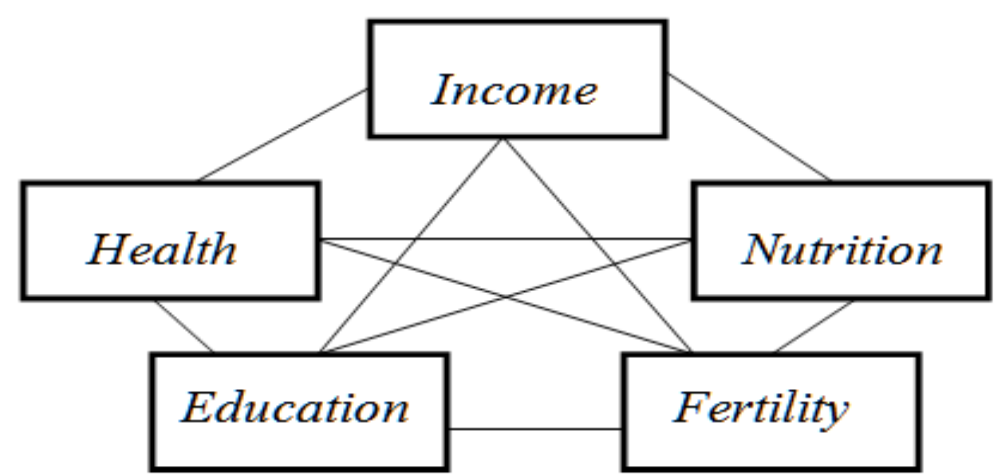

Sumber: Supriyatna, 1997

Gambar 3

Model Kebijakan Pembangunan Kemiskinan 
Berdasarkan atas data penelitian dan konsep seperti yang sudah dikemukakan bisa diartikan bahwa kebijakan mengenai program jaminan kesehatan merupakan kebijakan yang memiliki kesejalanan dengan rekomendasi yang dibuat. Selain itu data ini juga menunjukkan bahwa secara umum atau mayoritas, pembagian kartu atau peserta Jaminan Kesehatan Masyarakat sudah mencapai sasaran, walaupun harus diakui bahwa masih ada pemegang kartu atau peserta Jaminan Kesehatan Masyarakat yang masuk kategori tingkat pendapatan dan pendidikan tinggi, bahkan ada yang sudah terjamin melalui asuransi kesehatannya lain (Askes karena pegawai negeri), walau dengan jumlah yang sedikit.

Hasil wawancara yang dilakukan baik dengan opinion leader maupun petugas kesehatan di kecamatan dan kabupaten terungkap bahwa, masih adanya anggota masyarakat yang memeroleh kartu Jaminan Kesehatan Masyarakat terkait dengan waktu dan prosedur pendaftaran. Menurut hasil wawancara bahwa pengajuan masyarakat guna memeroleh Jaminan Kesehatan
Masyarakat dilakukan pada tahun 2011, dan pada saat itu beberapa orang (termasuk yang sekarang jadi PNS) pada saat itu statusnya sebagai orang yang memang secara aturan memenuhi persyaratan tersebut, sedangkan daftar diterima turun sekarang-sekarang.

Sementara itu, untuk pengetahuan yang ada di masyarakat mengenai Jaminan Kesehatan Masyarakat sebagai hasil dari kegiatan sosialisasi menunjukkan bahwa secara umum sosialisasi Jaminan Kesehatan Masyarakat pada khalayak sudah sampai ke sasaran (masyarakat tahu ada Jaminan Kesehatan Masyarakat (80,74\%) seperti ditunjukan oleh gambar 4. Walaupun harus diakui bahwa informasi yang sampai ke masyarakat sangatlah sederhana.

Pengetahuan masyarakat yang mayoritas terbatas pada adanya pengobatan gratis bagi masyarakat tidak mampu tetap sebagai suatu pengetahuan walaupun jika dianalisis dari sisi komunikasi kondisi ini bisa diartikan bahwa dalam kegiatan sosialisasi program Jaminan Kesehatan Masyarakat, telah terjadi kehilangan banyak informasi ketika informasi sampai ke publik sasaran.

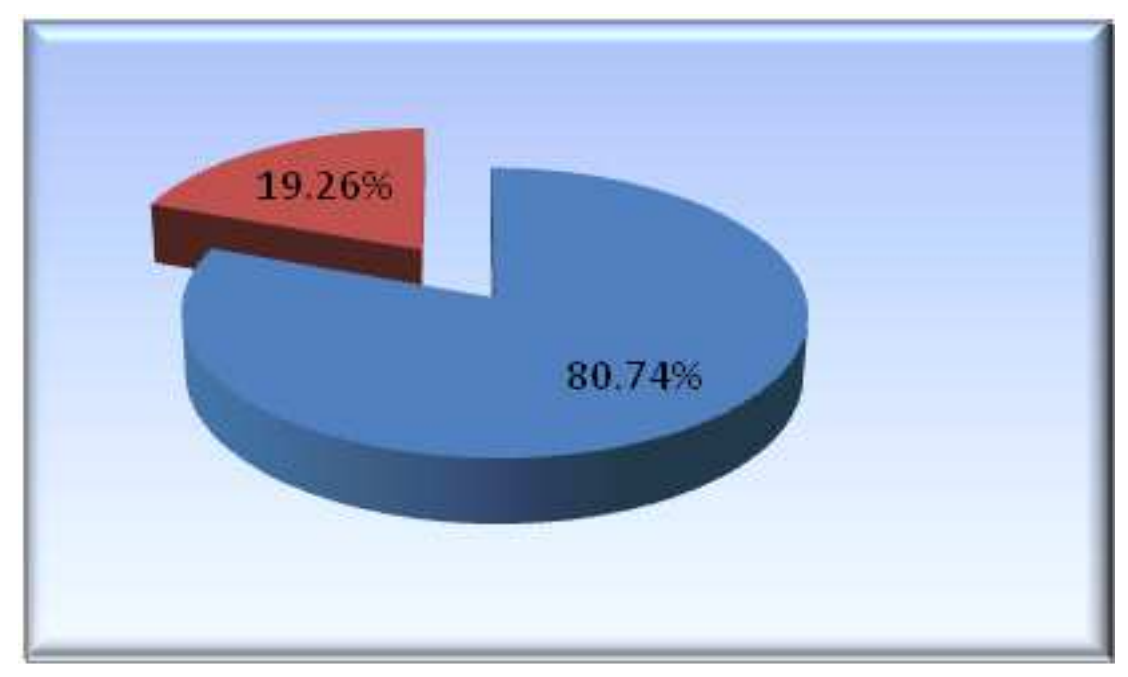

\section{Gambar 4 \\ Pengetahuan Masyarakat tentang Keberadaan Jaminan Kesehatan Masyarakat}

Pengetahuan masyarakat mengenai Jaminan Kesehatan Masyarakat sangat terbatas, dan pengetahuan masyarakat yang terbatas ini kebanyakan berasal dari masyarakat yang belum mengalami secara langsung atau primer (pengalaman yang terjadi lewat tindakan yang dialami lewat indranya) layanan kesehatan di rumah sakit, 
pengetahuan yang masyarakat dapatkan mengenai program Jaminan Kesehatan Masyarakat lebih merupakan hasil dari tindak komunikasi atau mendengar dari yang lain.

Pengetahuan masyarakat (publik) mengenai keberadaan Jaminan Kesehatan
Masyarakat diperoleh melalui berbagai saluran yang ada, hal ini ditunjukkan dengan hasil penyebaran angket yang hasil pengolahannya tercermin pada gambar 5 berikut:

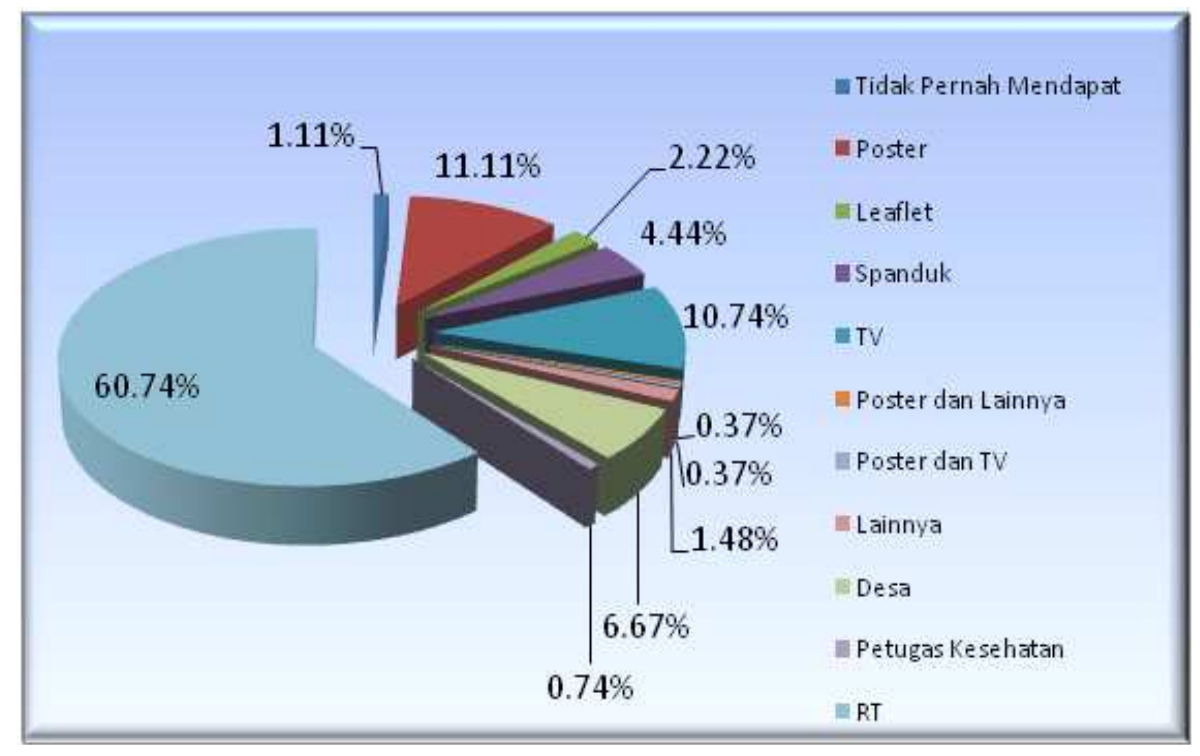

\section{Gambar 5 \\ Saluran Informasi Masyarakat tentang Jaminan Kesehatan Masyarakat}

Ada beberapa hal menarik dari gambar 5. Pertama, untuk program Jaminan Kesehatan Masyarakat, demikian banyak jenis dan saluran yang menerpa masyarakat, mulai dari media massa baik elektronik maupun non elektronik sampai komunikasi langsung yang bersifat antarpribadi. Kedua, sekalipun banyak saluran akan tetapi kebanyakan pengetahuan ataupun informasi yang dimiliki oleh publik sasaran berasal dari pemuka pendapat formal yang paling dekat dengan mereka, yaitu Rukun Tetangga, baru kemudian poster, dan televisi.

Gambar 5 juga bisa diartikan bahwa ternyata aspek proximity (kedekatan baik secara geografis maupun psikologis) di antara masyarakat sebagai publik sasaran sosialisasi dengan pemberi informasi masih tetap penting untuk diperhatikan. Kondisi ini juga bisa diartikan bahwa bagi masyarakat dengan karakteristik tingkat pendidikan yang rendah dan pendapatan yang kurang, ketua Rukun
Tetangga masih tetap menjadi pemuka pendapat yang banyak didengar masyarakat.

Komunikasi antara pemuka pendapat formal (sebagai sumber informasi utama) dengan publik sasaran dalam upaya menyosialisasikan program Jaminan Kesehatan Masyarakat dilakukan melalui komunikasi yang bersifat langsung atau tatapmuka. Hal ini berarti bahwa dalam proses sosialisasi program Jaminan Kesehatan Masyarakat dari pemerintah ke publik sasaran mengalami komunikasi paling tidak dua tahap, yaitu pemerintah melalui dinas instansi terkait seperti petugas Puskesmas ke ketua Rukun Tetangga atau Rukun Warga baru kemudian dari ketua Rukun Tetangga atau Rukun Warga sampai ke masyarakat.

Kalau digambarkan komunikasi yang paling banyak terjadi dalam sosialisasi Jaminan Kesehatan Masyarakat tersebut bisa ditunjukkan melalui gambar 6 berikut: 


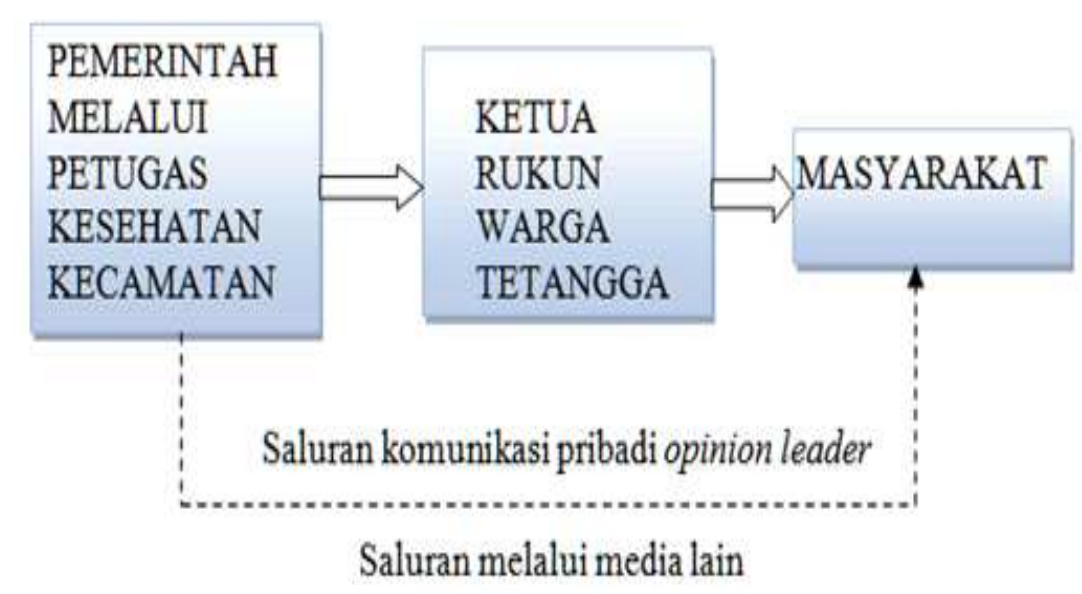

\section{Gambar 6 \\ Komunikasi Dua Tahap dalam Jaminan Kesehatan Masyarakat}

\section{Temuan Penelitian}

Hasil penelitian mengenai pengetahuan masyarakat atas program layanan kesehatan masyarakat menunjukkan bahwa masyarakat sudah mengetahui mengenai program Jaminan Kesehatan Masyarakat ini. Hal ini ditunjukkan dengan mayoritas jawaban responden, walaupun pengetahuan masyarakat mengenai Jaminan Kesehatan Masyarakat dilihat dari kedalaman atau luasnya informasi, secara tegas bisa dikatakan bahwa pengetahuan masyarakat mengenai Jaminan Kesehatan Masyarakat masih sangat terbatas. Data yang diperoleh dari penelitian melalui wawancara mendalam, menunjuk bahwa masyarakat hanya tahu sampai pada "pemerintah menyediakan layanan kesehatan gratis bagi masyarakat tidak mampu". Pengetahuan masyarakat tidak sampai pada jenis-jenis layanan kesehatan gratis bagi masyarakat, terlebih untuk pengetahuan lainnya yang bersifat lebih rinci, seperti macam pengobatan yang diberikan untuk rawat jalan ataupun macam pengobatan gratis yang diberikan pemerintah untuk rawat inap.

Pengetahuan masyarakat lebih terbatas lagi ketika ditanyakan berkaitan dengan mekanisme atau dasar yang dipakai untuk menetapkan seseorang berhak atau tidak berhak menerima kartu Jaminan Kesehatan Masyarakat.

Kurangnya pengetahuan masyarakat sebagai khalayak sasaran atas lengkapnya pengetahuan atau informasi mengenai Jaminan Kesehatan Masyarakat tidak akan menjadi persoalan ketika tingkat kemampuan pemerintah berkembang. Perkembangan tingkat kemampuan pemerintah yang ditunjukkan selain dengan semakin banyaknya golongan masyarakat yang bisa terjangkau oleh Jaminan Kesehatan Masyarakat, juga dilihat dari luasnya bidang layanan kesehatan yang diberikan pemerintah secara gratis baik untuk tingkat pertama maupun lanjut atau untuk rawat jalan dan juga rawat inap.

Kurangnya pengetahuan masyarakat mengenai mekanisme telah menjadi salah satu dasar pertanyaan yang muncul di masyarakat, mengapa seseorang memeroleh kartu Jaminan Kesehatan Masyarakat serta mengapa yang lainnya tidak memeroleh. Lebih jauhnya beberapa khalayak sasaran atau masyarakat mempertanyakan mengapa si " $A$ " pada saat ini dianggap mampu masih menerima aminan kesehatan masyarakat sementara si "B" yang pada saat ini dinilai kurang mampu tidak memperoleh kartu Jaminan Kesehatan Masyarakat? Demikian minimnya pengetahuan masyarakat mengenai mekanisme dan dasar pemberian kartu Jaminan Kesehatan Masyarakat tahun 2013 ini.

Lebih jauh, kurang lengkapnya pengetahuan khalayak sasaran atau masyarakat atas Jaminan Kesehatan 
Masyarakat terkait dengan; pertama, kekecewaan masyarakat dalam layanan kesehatan yang diberikan oleh pemerintah, padahal memang menurut aturannya jenis layanan tersebut tidak disediakan oleh pemerintah.

Kedua, ketidaklengkapan pengetahuan masyarakat atas Jaminan Kesehatan Masyarakat memunculkan konflik antara masyarakat yang ingin mendapat layanan dengan kelompok health provider, masyarakat hanya tahu pokoknya sakit apapun diobati gratis, sementara rumah sakit hanya memberi layanan gratis sesuai dengan jenis layanan yang sudah tertera dalam aturan. Ketiga, sekalipun pemerintah telah berbuat banyak tetapi masih diinterpretasi bahwa pemerintah tidak banyak berbuat.

Hal lain yang menarik sebagai temuan penelitian ini terkait dengan saluran dan peran penting dari pemuka pendapat di wilayahnya. Peran pertama dari pemuka pendapat berkaitan dengan posisi pemuka pendapat sebagai saluran informasi utama bagi masyarakat kurang mampu dan berpendidikan rendah. Sebagai konsekuensi dari posisi ini maka komunikasi yang dibangun adalah komunikasi yang bersifat antarpribadi dan kelompok. Ini berarti bahwa pengetahuan yang ada di masyarakat mengenai Jaminan Kesehatan Masyarakat merupakan hasil kontribusi yang cukup besar dari para pemuka pendapat.

Salah satu cara yang dilakukan pemuka pendapat dalam menyosialisasikan program Jaminan Kesehatan Masyarakat pada masyarakat yang ada di sekitar adalah melalui penyederhanaan pesan atau informasi. Dari sekian banyak informasi yang didapat pemuka pendapat mengenai Jaminan Kesehatan Masyarakat, pemuka pendapat menyampaikan kepada masyarakat cukup dengan isi pesan yang singkat bahwa "sekarang kalau sakit bisa berobat dengan gratis". Sadar atau tidak terhadap apa yang dilakukannya, akan tetapi yang jelas apa yang dilakukan para pemuka pendapat di wilayah kajian memiliki kesejalanan dengan temuan beberapa konsep atau pemikiran mengenai model adopsi inovasi AIDA (awarnes, interes, desire, action), ataupun model hierarki efek, juga model adopsi Robertson juga model adopsinya Rogers.

Selain kesederhanaan interpretasi pesan yang dibuat ataupun disampaikan pemuka pendapat atau opinion leader, aspek lain yang mendukung sampainya sosialisasi Jaminan Kesehatan Masyarakat pada khalayak sasaran secara mudah adalah program ini menyangkut kepentingan diri khalayak sasaran, oleh karena itu masyarakat selain hanya menerima pesan melalui penyuluhan yang dilakukan di kantor desa, masyarakat yang menjadi khalayak sasaranpun secara aktif mencari informasi pada anggota masyarakat lain yang ditokohkan di sekitar tempat tinggalnya, yang biasanya ke ketua Rukun Tetangga ataupun ketua Rukun Warga. Secara singkat faktafakta penelitian menemukan bahwa terkait dengan kepentingan dirinya, masyarakat bisa menjadi orang-orang yang aktif dalam pencarian informasi walaupun pencarian dilakukan dengan cara dan tingkat yang sederhana.

Pola komunikasi dalam sosialisasi program Jaminan Kesehatan Masyarakat sekaligus menemukan titik ungkit guna meningkatkan keberhasilannya seperti berikut: 1) Dalam program Jaminan Kesehatan Masyarakat, masyarakat merupakan publik yang oleh Oxley (1993) disebut sebagai publik klien yaitu orang atau sekelompok orang yang berada dalam sebuah kondisi tertentu (bisa kecewa, tidak paham, terbaikan, dan lain-lain); 2) Ketua Rukun Tetangga atau Rukun Warga merupakan orang-orang yang memiliki posisi sebagai sumber informasi utama masyarakat dalam program Jaminan Kesehatan Masyarakat, maka kelompok orang ini tepat untuk dikategori sebagai publik target sebagaimana dikemukakan Oxley (1993). 3) Ini berarti bahwa dalam upaya meningkatkan pengetahuan bahkan pemahaman masyarakat mengenai Jaminan Kesehatan Masyarakat, kelompok orang yang harus diberi perlakuan pertama berupa peningkatan pengetahuan dan pemahaman adalah ketua Rukun Tetangga ataupun Rukun Warga. 4) pemerintah dengan berbagai institusi yang terkait (institusi yang berwenang), perguruan tinggi serta elemen lain (yang merasa ikut terpanggil, 
bertanggungjawab bagi keberhasilan) program Jaminan Kesehatan Masyarakat mengikuti berpikirnya Oxley (1993), masuk kategori sebagai publik aksi.
Secara sederhana jalinan di antara ketiga komponen itu tergambar melalui gambar berikut :

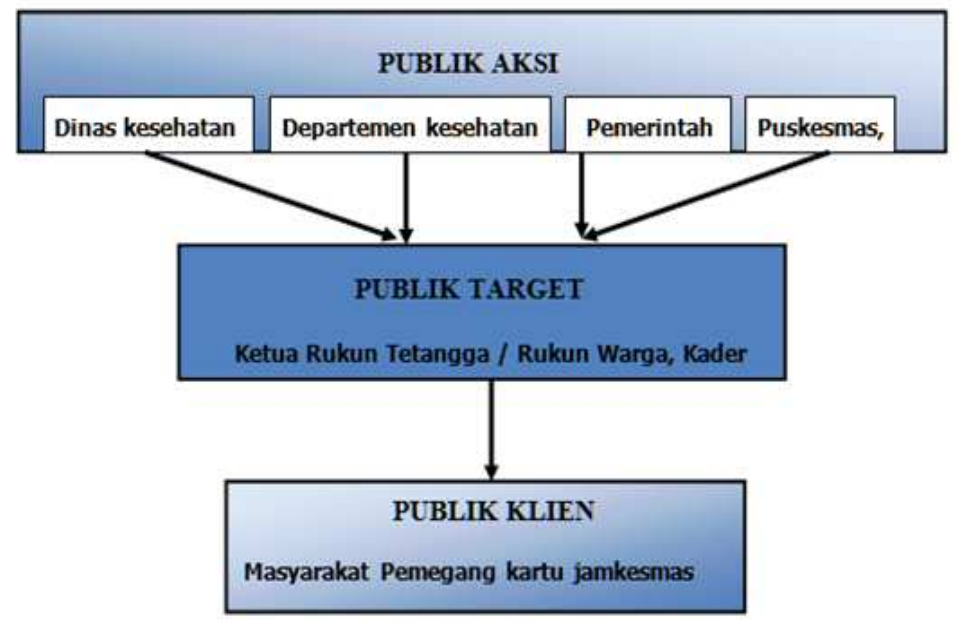

Gambar 7

Model Arah Aliran Informasi dalam Program Jaminan Kesehatan Masyarakat

\section{PENUTUP}

\section{Simpulan}

Karakteristik pengguna kartu Jaminan Kesehatan Masyarakat, mayoritas sudah mencapai khalayak sasaran yaitu kelompok masyarakat yang memiliki tingkat pendidikan yang kurang, dan juga pendapatan yang rendah.

Mayoritas pemilik kartu Jaminan Kesehatan Masyarakat tahun 2013 didapat oleh khalayak yang menjadi target dari program Jaminan Kesehatan Masyarakat

Model komunikasi dalam sosialisasi kartu dan layanan Jaminan Kesehatan Masyarakat lebih bersifat dua tahap, dengan alur informasi dari petugas ke tokoh masyarakat (ketua Rukun Tetangga dan Warga) baru kemudian ke masyarakat.

Pemuka Pendapat (opinion leader) dalam sosialisasi Jaminan Kesehatan Masyarakat berperan banyak dalam menyosialisasikan program Jaminan Kesehatan Masyarakat melalui penyederhanaan pesan.

Bila terkait dengan kepentingan dirinya, masyarakat bisa menjadi orang-orang yang aktif dalam pencarian informasi.

\section{Saran}

Pemerintah telah berbuat banyak untuk kesehatan masyarakat, agar pemerintah tidak dipersepsi tidak banyak berbuat untuk menyehatkan masyarakatnya maka disarankan agar masyarakat diberi banyak informasi secara lengkap dan benar.

Dalam upaya meningkatkan pengetahuan dan pemahaman masyarakat mengenai Jaminan Kesehatan Masyarakat publik target pertama yang harus ditingkatkan pengetahuannya adalah oleh para pelaku perubahan terkait dengan Jaminan Kesehatan Masyarakat adalah para pemuka pendapat formal yang ada di sekitar mereka yaitu ketua Rukun tetangga dan Rukun warga.

$$
\text { Mengingat sosialisasi Jaminan }
$$
Kesehatan Masyarakat yang berjenjang dan bersifat hierarkis mengakibatkan hilangnya sebagian informasi ketika sampai ke tujuan, agar dalam sosialisasi, komunikasi yang bersifat langsung diperkuat dengan komunikasi bermedia yang relatif lengkap 
namun menarik bagi pemuka pendapat.

\section{DAFTAR PUSTAKA}

\section{Buku:}

Embong,

Abdul

(2003).Pembangunan

Kesejahteraan.Malaysia: Universiti Kebangsaan Malaysia.

Gorman, Lin dan David McLean. (2003). Media and Society in The Twentieth Century. Blackwell Publishing.

Kriyantono, Rahmat.(2006). Teknis Praktis Riset Komunikasi. Jakarta: Prenada Media Group.

MacBride, Sean, at.all. (1983). Komunikasi dan Masyarakat Sekarang dan Masa Depan, Aneka Suara Satu Dunia. Jakarta: Balai Pustaka.

McAnany, Emile G. (1980). Communications In The Rural Third Word. New York: Praeger .

Morse, Suzanne W. (2004). Smart Community, How Citizens and Lokal Leaders Can Use Strategic Thinking to Build a brighter Future.San Francisco: Jossey-Bass,.

Nasution, Zulkarimein. (1989). Teknologi Komunikasi dalam Perspektif. Jakarta: LP-FEUI.

Oxley, Harold. (1993). Public Relations Prinsip, Persiapan dan
Pengembangannya. Jakarta: Gunung Mulia.

Sapuan, dkk. (1994). Pembangunan Pertanian dalam Penanggulangan Kemiskinan. Jakarta: PERHEPI.

Singarimbun, Masri. (1998). Metode Penelitian Survay,. Jakarta: LP3ES.

Supriyatna, Tjahya. (1977). Birokrasi Pemberdayaan dan Pengentasan Kemiskinan. Bandung: Humaniora Utama Press.

Susanto, Astrid S. (1995). Globalisasi dan Komunikasi. Jakarta: Pustaka Sinar Harapan.

Van den Ban, A.W dan H.S. Hawkins. (1999). Penyuluhan Pertanian. Yogyakarta: Kanisius.

Zaltman, Gerald, Philip Kotler, dan Ira Kaufman. (1972). Creating Social Change. New York: Holt Rinehart and Winston. Inc.

\section{Makalah:}

Pendit, Putu Laxman. (2007). Teori-teori informasi. Jakarta: Perpustakaan Pusat Universitas Indonesia.

\section{Surat Kabar:}

Anonim.(2007).Indonesia Kekurangan Tenaga Penyuluh. Pikiran Rakyat. 18 Mei, hal 6. 